\title{
The Long Journey: Maternal Trauma, Tears and Kisses in a Work by Chantal Akerman
}

\author{
Griselda Pollock
}

\begin{abstract}
I've talked so much about my mother in these films. Have I really worked so many years on her, around her, about her? (Or, as I have just read in a review, against her. Not her personally, especially not that. It's more complex than in the review) Chantal Akerman.

Memory is always reinvented but with a story full of holes it's as if there is no story left. What to do then? Try to fill the holes-and I would say even this hole- with an imagination fed on everything one can find, the left and the right and in the middle of the hole. One attempts to create one's own imaginary truth. Chantal Akerman. ${ }^{1}$
\end{abstract}

Preparing to make the fiction film Tomorrow we Move (2004), analysed in this issue by Alison Rowley, Chantal Akerman visited her mother in Brussels one Sunday and asked Renaud Gonzalez to film an impromptu conversation. A piece of 'research' for a prospective scene that would later be scripted for and performed by two professional actors (Aurore Clément and Sylvie Testud) in the commercial movie, this informal encounter filmed on a little digital camera, which recorded Chantal Akerman and her mother on screen together for the first time, was subsequently reworked into a dual-screen projection and framed by a two-part sculptural installation that was exhibited in Marian Goodman's Gallery in 2004 in Paris and New York. The title of the installation was To Walk Next to One's Shoelaces Inside an Empty Fridge, and it was also shown at the Camden Arts Centre, London in 2008 (referenced hereafter as Walking/Marcher). ${ }^{2}$

I first encountered this piece, however, unexpectedly in Berlin at the Jewish Historical Museum in 2006, where Akerman's installation was paired with the first showing in Berlin of a major exhibition of Berlin-born painter Charlotte Salomon's Life? Or Theatre? (1941-2). Salomon was murdered in Auschwitz at the age of 26 having created a major work of 769 paintings that in part invented what I have called a 'theatre of memory' through which to examine the lives, and the tragic deaths, of her own mother and grandmother, both of whom committed suicide. Seeing Akerman's work in which she 
and her mother eventually talk about the latter's experiences during the Shoah in the context of the Charlotte Salomon installation clearly overdetermined my reading of the work, and my own history of maternal bereavement and motherhood overlaid my affective responsiveness to it.

I have to admit that I was emotionally undone by seeing the Akerman installation. Yet it was also restorative. Its deeply affecting tone relieved me from a temporary depression that had deprived me of the ability to write. My writer's block was, I think, occasioned by the unanticipated intensity of missing my own daughter who had just left for New York to study, leaving me in a situation not unlike Chantal Akerman's own mother, so tenderly commemorated in an earlier film, News from Home (1976), where long takes of the streets and subways of Manhattan are punctuated by the film-makerdaughter's voice reading the letters from home written in halting French by a brave but clearly sorrowing mother, at once wishing wholeheartedly for her daughter's artistic selfrealisation and, just as unbearably, missing her. Seeing Akerman's installation made me simply want to write, and write about it.

Akerman had been thinking about doing the piece of work that became Walking/Marcher for a long time. At its core was not, however, her mother, the haunting and troubling presence of so many of her movies since Jeanne Dielmann (1975), News from Home (1976), and Les Rendez-vous d'Anna (1978). In 1997, I met Chantal Akerman at an event organized by the DIA Art Foundation in New York, just after having seen her first installation work: Bordering on Fiction: D'Est (1995) then installed at the New York Jewish Museum. D'Est is about the landscapes of Eastern Europe haunted by the loss of the disappeared Jewish communities. I learned then that the filmmaker was thinking about creating a film about her grandmother who had been an artist and had perished in Auschwitz, leaving as her only trace some written pages and a painting in a diary begun when she was still a teenager. ${ }^{3}$ This turn to subjects with invested Jewish histories was new to me, since I had not been able to see Akerman's earlier work, Histoires d'Amérique (1989), inspired, she once told Godard, by the work of Isaac Bashevis Singer. Akerman's work about her grandmother was finally realised in 2004, but in two quite different formats.

Griselda Pollock, The Long Journey: Maternal Trauma, Tears and Kisses in a Work by Chantal Akerman Studies in the Maternal 2(1) 2010, www.mamsie.bbk.ac.uk 
By means of understated references, the film Tomorrow we Move opens itself to the issues of the intergenerational transmission of trauma and memory across the catastrophe of the Shoah, through what Akerman calls 'the sacrificed generation'. This phrase refers to the Jewish young men and women who survived the Shoah, but had to sacrifice their own adolescent dreams to ensure the resumed continuity of often desperate daily life. Their initial trauma, unmourned, and their sacrificed identities, may have been passed, unspoken, onto the second generation, their children. But what is transmitted is a void:

People of my parents' generation told themselves: we are going to spare them the story of what happened to us. Because they did not transmit their histories, I searched for a false memory, a kind of imaginary, reconstructed memory rather than the truth. ${ }^{4}$

Like Akerman herself, some of these children became creative people, while they remain haunted by the presence of a past not entirely their own. My proposition, resulting from the encounter with Walking/Marcher is that Chantal Akerman's work as a whole can now be read retrospectively as a long journey home, namely as a journey towards the trauma that is finally claimed and transformed - trans-formed by a process of filmmaking that hovers undecidably between fiction and history through the creative devices that Janet Bergstrom named 'invented memories', and Alisa Lebow identified as 'transitive autobiography. ${ }^{5}$

I first encountered Akerman's cinema at the Edinburgh Film Festival in 1975 when I was still a rookie in emerging radical cultural politics and the new, cinematic avant-garde. As part of the Psychoanalysis and Cinema event at the Festival, Akerman's recently completed three-and-a-half hour film, Jeanne Dielmann 23 Quai du Commerce 1080 Bruxelles, was screened. I must admit that in $1975 \mathrm{I}$ had no means of immediately appreciating this film. I felt aggressed by the film's duration, its slow deliberate attentiveness to 'nothing' but the silently performed ritual of a woman's emotionally immiserated daily life. The film's incongruent themes-domesticity and prostitution-were, however, already 'feminist' issues. Furthermore, it would not take much time for my theoretical and cultural education to improve sufficiently by means of viewings of more Godard movies, joining a Screen magazine reading group and attending SEFT film

Griselda Pollock, The Long Journey: Maternal Trauma, Tears and Kisses in a Work by Chantal Akerman

Studies in the Maternal 2(1) 2010, www.mamsie.bbk.ac.uk 
education weekends to come to terms with the formal strategies deployed by Akerman and to see these as equally part of an emerging feminist aesthetics in cinema. Laura Mulvey's foundational essay that ignited feminist film theory would appear in Screen in 1975, and my close association with key artists in the development of feminist avantgarde art and film practices like Mary Kelly further extended the resources with which I could return to Akerman's extraordinary film and recognise its beautiful ambivalence towards the mother-figure, its 'feminist' refusal of the classic film structure of shot and reverse shot, of cutting and fast editing. Instead, the fixed, low camera position and the long takes were welcomed as signs of a feminist grammar that sought to avoid objectifying woman within cinema but might allow, by such radical disobedience from Hollywood conventions, a representation of woman as subject, a narrative of feminine subjectivity in its subjection to the domestic as well as in the loving attention of the daughter filmmaker to the typically overlooked and unconsidered gestures of daily, housewifely life.

Feminists argued, of course, over what the murder in the final hour of the film signified; at that time, it was usually considered in terms of the question of sexual pleasure. We accepted the long period of the post-killing woman's inactive sitting as the introduction of the space of reflection in lieu of the usual tidying up, ideologically packing away of the problem that is the norm in classic Hollywood entertainment cinema.

Subsequently, I followed Akerman's work with great interest and taught her films, most notably Jeanne Dielman regularly for about 12 years - inflicting its longueur and possible tedium on generations of students even less able to tolerate its slowness given the increased tempo of contemporary post-modern cinematic editing and the speed of image-change in music videos. At the Jewish Museum in New York, in 1997 I experienced Akerman's first 'art' installation, created initially for the Walker Art Gallery, Minneapolis in 1995. Independent cinema as a major art form had lost its institutional base just as the visual arts embraced new media as their privileged form. Akerman was going to bridge the two with an installation artwork based on a recently made film. It was called D'Est: From the East.

Griselda Pollock, The Long Journey: Maternal Trauma, Tears and Kisses in a Work by Chantal Akerman Studies in the Maternal 2(1) 2010, www.mamsie.bbk.ac.uk 
Made possible by the break up of the Soviet Union and its extended empire in 1989, by 1993 Chantal Akerman had made several journeys with her crew travelling east from Berlin to Moscow across the newly democratised countries of Eastern Europe. The result was a full-length film in which the signature features, fixed camera, long travelling shots, slow drive-by filming, was now applied to the newly exposed landscapes of Eastern Europe. The camera's agnostic attention to landscapes, roadsides, bus stations or people walking in the street disclosed to the viewer, without voice-over or commentary, a terrible truth, an unbearable revelation of accumulating absence combined with a haunting sense of the menace in these ordinary daily rituals. This was the landscape; 'this is the place', as lone survivor Simon Srebnick declares in the first spoken words of Claude Lanzmann's Shoah (1985) when taken back to the death camp of Chelmno. ${ }^{6}$ Unlike Lanzmann, Akerman was not looking for witnesses to the destruction of European Jewry. She simply filmed the place, as it was, fifty years after most of the Jewish populations of these villages, towns, and countrysides were ruthlessly deported and murdered. Kept in a kind of historical deep freeze by economic stagnation under Communism, the landscapes of Poland or the Ukraine in the mid-1990s looked unchanged from those of 1939, with little technological advancement. The landscapes were the same, except for the aching absence that this filming unostentatiously made visible by virtue of its almost Bazinian cinematic attention to these places that Belgian-born Akerman was seeing for the first time, yet came to experience as being vicariously familiar, as a lost family history seeped through the scenes seen of the Eastern Europe of the 1990s. Scenes of Russians in wintry nights walking the streets or waiting at bus stops came to resonate for a child who had spent a childhood imagining over there. 'Over there' is the euphemism used by Jewish survivors from Poland for their former home that was also now the unmarked cemetery of both family and an entire disappeared civilisation of Jewish Europe. These modern day Eastern Europeans walking and queuing became a reminder, an evocation of earlier queues, other streams of people passively waiting transport, a different kind of transport, to an unimaginable destination. Such streams of walking people had become scenes through contemporary filming, and that footage had been recirculated in documentaries such as Alain Resnais's Night and Fog (1955) to install these images in cultural memory.

Griselda Pollock, The Long Journey: Maternal Trauma, Tears and Kisses in a Work by Chantal Akerman 
In the installation format of 1995 , the film $D^{\prime} E s t$ was screened cinematically in the first room as a $35 \mathrm{~mm}$ film. In the second room, the same film was streamed across $24 \mathrm{TV}$ monitors choreographed by computer-generated timings and editings to make imagery flow, revealing its own symptomatic repetitions. Here was the beginning of a rewriting of the movement of the cinematic image into a stream that would relate to new technologies as much as it evoked older, modernist and psychoanalytical notions of streams of consciousness. The darkened room was crowded with grouped plinths bearing the luminous box that heightened the movements and the encounters with the faces and places of an Eastern Europe that Akerman discovered that she already knew-she who was born in Brussels, spoke French, loved Godard and made French new wave movies. She is the child of survivors of the Holocaust and in her Brussels home, the foods of Eastern Europe often - and inexplicably until this moment of re-encounter - displaced the western European cuisine typical of her Belgian school friends and neighbours.

In the final room a single TV monitor sat on the floor of an otherwise empty space. On its surface, an indistinct image of a night sky in the city punctuated by the odd street lamp played. There was a voice over. It was the accented voice of Akerman herself. She begins by reading in perfect Hebrew the second commandment, which forbids the making of graven images. Jewish law prohibiting the image and the imageless image collide. She talks about making films and having to know, or not know in advance what the film is about. Yet she says she only finds out what the film is about once it is made.

And slowly we all realise that it is the same thing that is revealed. A little like a primal scene. And the primal scene for me, although I fight against it and end up in a rage. I have to face facts. It is far behind and always in front of all images barely covered by other luminous or even radiant ones. All images of evacuation, of walking in the snow with packages toward an unknown place, of faces and bodies placed next to one another... And it was always like that. Yesterday, today and tomorrow, there were, there will be, there are at this very moment people whom history (which no longer has a capital H) whom history has struck down. People who were waiting there, packed together, to be killed, beaten or starved or who walk without knowing where they are going, in groups or alone. There is nothing to do. It is obsessive and I am obsessed. Despite the cello, despite cinema. Once the film is finished I said to myself, "so, that's what it was; that again."

That, again. But this appears to be the first time that what that is, again and again, has taken form, has found its spaces in a historical landscape of Eastern Europe and found its faces in the others, still there, who cannot replace their Jewish neighbours who were

Griselda Pollock, The Long Journey: Maternal Trauma, Tears and Kisses in a Work by Chantal Akerman

Studies in the Maternal 2(1) 2010, www.mamsie.bbk.ac.uk 
disappeared after they were rounded up, and forced to walk with packages towards forms of transport and modes of dying.

Two words. That and again. That, like it, is indicated but not specified. Again reminds us of repetition. It is linked to obsession. Thus by taking the journey to the places and spaces of a history she had somehow, vicariously, known while being born and growing up in Brussels and that her films had symptomatically registered as one of their many tenors, threads, tracks, pressures, Akerman returned to the primal scene of the sources of her anxiety: she located and faced what we now called intergenerational transmission of trauma.

Like many children of survivors, Akerman belongs to what is called a second generation who experience the normal unspoken transmissions between parents and children, except that what appears to be part of the cultural passing on is massive trauma; that which the parents do not tell, or even know to tell. The parent's non-narrated past inhabits the child's psychological present with a permanent movie, whose images are supplied by other films and photographs surreptitiously borrowed from and fed by real movies and images that offered themselves to give shape to shapeless intimations of unspoken parental experiences. The children live inside memories of things they never experienced, or they are haunted with an unlocated sense of terror or anxiety, even having hallucinatory images from another time and place. Helen Epstein was one of the first writers to explore these sensations. She writes of feeling that she carried a buried box, bomb or tomb within her, which she was able to relieve only by meeting with other children of survivor families who acknowledged similar sensations and hauntings. The British sociologist Anne Karpf was one of the first British writers to explore what she named 'living with the Holocaust'. Israeli novelist David Grossman made it the topic of the first part of his novel See Under Love. Israeli writer and actor, Gila Almagor wrote it into her autobiographical novel The Summer of Aviya. Cartoonist Art Spiegelman wrote his graphic novel about it in the form of Maus: A Survivor's Tale. ${ }^{7}$

The acknowledgement of the very possibility of intergenerational transmission of trauma first emerged, however, during the 1970s when psychoanalysts began to find

Griselda Pollock, The Long Journey: Maternal Trauma, Tears and Kisses in a Work by Chantal Akerman Studies in the Maternal 2(1) 2010, www.mamsie.bbk.ac.uk 
themselves working with children of the surviving generation and identifying what Judith

\section{Kestenberg first described as transposition:}

Transposition describes the uncanny experience where the past reality of the parent intrudes into the present psychological reality of the child. Transposition is an anomalous version of the ordinary psychological processes whereby the wishes, desires, fantasies, ideals and experiences of a parent are unconsciously transmitted to a child. Transposition is generational transmission run amok.

Transposition inverts the logic of time; but it also places history inside the psychological formation of the child born after its occurrence:

Transposition turns the ordinary dimensions of time and space inside out...Transposition also refers to reversals of ordinary time, whereby the temporal position of parent and child are exchanged. Since the parent's past occupies the psychological space that would ordinarily belong to the current life of the child, the child must give up its right to exist in its own present. ${ }^{8}$

What follows from such insights not only concerns the recognition of the transmission of history as trauma, as being occupied by what is missing, but it makes us explore the specific mechanisms and processes by which this inheritance of the traumatic void may be negotiated and creatively transformed.

Of her maternal grandparents Chantal Akerman has written:

Like two lambs, they let themselves be taken by the Germans. They believed the Red Cross card would protect them. What happened to them over there, afterwards? Like everyone else I try to imagine it, even if they say it's impossible to imagine. Yet, I let myself imagine something anyway, and the worst part of it is imagining them naked. Him as well as her. "Naked as a worm", as they say. Of him, my grandfather there is only an identity photo. At least, there's that, even if it's only that. There are also some phrases that escape from time to time from my mother. That is how I know that he was a wonderful man, very religious, who closed his eyes to my grandmother's modern ways. It seems he let her do what she wanted. And of my grandmother there remains her young girl's notebook. My mother gave it to me. She said, it will protect you. She gave it to me when I was in need of being protected and she felt powerless. She gave it to me instead of talking. She gave it to me, that's the point. It's been mine since 1984, I think. In fact everything changed in 1984. I sang so hard I exploded. Since then I explode from time to time. (My emphasis) ${ }^{9}$

Explosion was the concluding gesture of Akerman's very first film: Saute ma

Ville: Explode my Town (1968). In the text that I have quoted above, Chantal Akerman

Griselda Pollock, The Long Journey: Maternal Trauma, Tears and Kisses in a Work by Chantal Akerman

Studies in the Maternal 2(1) 2010, www.mamsie.bbk.ac.uk 
articulates three important dimensions of being a child of survivors of the Holocaust. The child grows up without grandparents. ${ }^{10}$ The mystery of the orphaned parent transmits to the child an additional enigma to be deciphered by attempting to imagine both the beings of the parent's missing parents and, in the particularity of historical catastrophe that destroyed European Jewry in the middle of the twentieth century, the horror of their ending, namely their naked deaths in Auschwitz. Thus what has to be integrated is not merely the succession of generations within which the child 'normally' takes its place, but the traumatic, historical rupture - that takes places over there in the parlance of Jewish survivors from Poland - of which the child is the inheritor. She is not born into life and its reassuring cycles; it is untimely deaths that have somehow to be imagined if only to incorporate them into the grounds of living on after. ${ }^{11}$

Secondly, the absence and the unimaginable but always to be imagined end of the parents of the mother are both marked, and compensated for, by fetishising relics that function as both substitutive memorials of the missing and markers of their horrible absenting: an identity photograph in one case and a notebook-diary in the other. The photograph of the grandfather installs an image and supports what Marianne Hirsch, in her analysis of the households of survivor families with their fractured family albums, calls post-memory. Post-memory is mediated by the photographic index of another time, place, world and generation; it is a space in the child-subject that links it with a world and events s/he personally never knew but with which s/he acquires a dislocated, imaginary intimacy. ${ }^{12}$ As in the case of Art Spiegelman, author of the second generation tale, Maus, photographs punctuate the vast tracts of missing families and worlds from which the child is exiled while yet being inhabited through the intergenerational transmission of trauma. ${ }^{13}$

Of her grandmother, Chantal Akerman also holds in her hands a material object, a diary written by her missing grandmother's own hand when she was herself a teenager and young woman. It contains her confessional writing and a watercolour portrait of a woman. Writing and painting mark the paper with two actions that defy the limited identities of the religious Jewish woman in particular, and the Western bourgeois woman in general, neither of whom is expected to be a writer or an artist. Writing and painting mark ambition and desire for creative self-inscription, and the longing for that which is 
missing; someone with whom to speak so as to be recognised in what is experienced as the exiled condition of the thinking, feeling, creative and, above all, modernising woman. ${ }^{14}$ Luce Irigaray's poignant evocation of the condition of the feminine subject in phallocentric culture as a 'derelict' figure abandoned in a cultural desert is evoked perfectly in the words of this sole relic of the being of Sidonie Erenberg:

I am a woman!

That is why I cannot speak all my desires and my thoughts out loud. I can only suffer in hiding. So to you, this journal of mine I want at least to say some my thoughts, my desires, my sorrows and my joys and I will be sure that you will never betray me because you will be my only confidant. ${ }^{15}$

How closely this tiny passage resonates with the writing of Virginia Woolf who, in the same decades of the early twentieth century, would also ponder on the internal and external censorship on the full articulation of woman as desiring, thinking, imagining subject. Culminating in her lecture/essay of 1931, 'Professions for Women', Woolf famously imagined the deadly struggle waged by the would-be woman writer against the inner voice of patriarchal ideology that took the form of the 'Angel in the House'; a bourgeois feminine ideal offered to women by that culture that forbade the woman to think for herself. The Angel, that threatened to take the heart and the body out of the woman's writing, had to be killed.

Now that she had rid herself of falsehood, the young woman had only to be herself. Ah, but what is "herself"? I mean what is a woman? I assure you, I do not know. I do not think that anybody can know until she has expressed herself in all the arts and professions open to human skill. ${ }^{16}$

Woolf continues to present her own experiences as a writer who, in following the free flow of imaginative creation is catastrophically brought up against the hard wall of social censure when she dares to think about the body, desire, sexualities prohibited by the culture in woman. 'The first - killing the Angel in the House - I think I solved. She died. But the second, telling the truth about my own experiences as a body, I do not think I solved. I doubt any woman has solved it yet. ${ }^{17}$ We can dare to reach across time to another, perhaps the most famous diary of the twentieth century, in which a young Jewish writer-to-be living in hiding in the early 1940s used the imaginative spaces of her diary, addressed to her invented, phantom-friend named Kitty, to explore her own sexual

Griselda Pollock, The Long Journey: Maternal Trauma, Tears and Kisses in a Work by Chantal Akerman

Studies in the Maternal 2(1) 2010, www.mamsie.bbk.ac.uk 
awakening, only to have these historically significant passages about feminine subjectivity and sexuality censored from the published form of The Diary of a Young Girl that appeared in 1947. I am, of course, thinking of the work of Anna Frank, returned to us in its full historical significance as a feminist text only in the 1990s, fifty years after her dreadful and lonely death in Bergen-Belsen. ${ }^{18}$

To find the traces in a fragmentary private diary of a young Jewish woman from Poland ca.1920-22 of what we know to be the central tropes of emergent feminist modernism, emplots the larger cultural history of the twentieth century into the historical catastrophe of the Jewish world in Europe which passes through the intervening generation represented by Nathalia (Nelly) Akerman, both the mother of one of the most renowned contemporary filmmakers of the later twentieth century, and the embodiment of the traumatic breaching of historical succession from the lost woman artist who was her own mother.

The third aspect I want to note in the passage quoted above is that Akerman states that her mother gave her the diary in 1984 'instead of talking'. As Bracha Ettinger writes in her Notes on Painting: Matrix Halal(a) Lapsus in 1992:

My parents are proud of their silence. It is their way of sparing others and their children from suffering. But in this silence, all is transmitted except the narrative. In silence, nothing can be changed in the narrative which hides itself. ${ }^{19}$

Silence was the mark of Jeanne Dielman, 23 Quai du Commerce, 1080 Bruxelles (1975), the film which made Akerman one of the major names of a new feminist counter-cinema. Lasting three and a half hours, the film tracks three days in the life of a single mother raising a son in emotionally desolate isolation, earning money by part-time prostitution, whose rigorous routines that ensure the continuation of such a non-life are disorganised by the eruption of a violence of unexplained 'feeling'. The film ends with a woman sitting in silence for the last seven minutes, after killing her client in what I take now to be a gesture of resistance to and revulsion from her hitherto mute and routinised endurance. Critics then and since have always sensed that films such as this and News from Home were ambivalent 'love letters' to the/her mother. ${ }^{20}$ But that language fails to acknowledge the inhabitation, the transcryptum, that the pages of the multiply-inscribed grandmaternal diary already carry. ${ }^{21}$

Griselda Pollock, The Long Journey: Maternal Trauma, Tears and Kisses in a Work by Chantal Akerman Studies in the Maternal 2(1) 2010, www.mamsie.bbk.ac.uk 
Something could not be spoken; yet there was a transmission mediated by this text-object. Twenty years passed until they filmed together and the return to the diary enabled the beginning of talking, which is what we are invited to witness in the installation.

III

To Walk Next to One's Shoelaces Inside an Empty Fridge is very different from the finely tuned, economic and affecting movie, Tomorrow we Move, in which one of the many people who come to inspect the apartment of the heroine of the film finds, secretly takes, and then returns a notebook forgotten in an overstuffed cupboard. Unable to sleep, the daughter begins to read it until she is joined by her equally insomniac mother. Together they peruse it, until the mother reaches out, strokes her daughter's face and kisses her cheek.

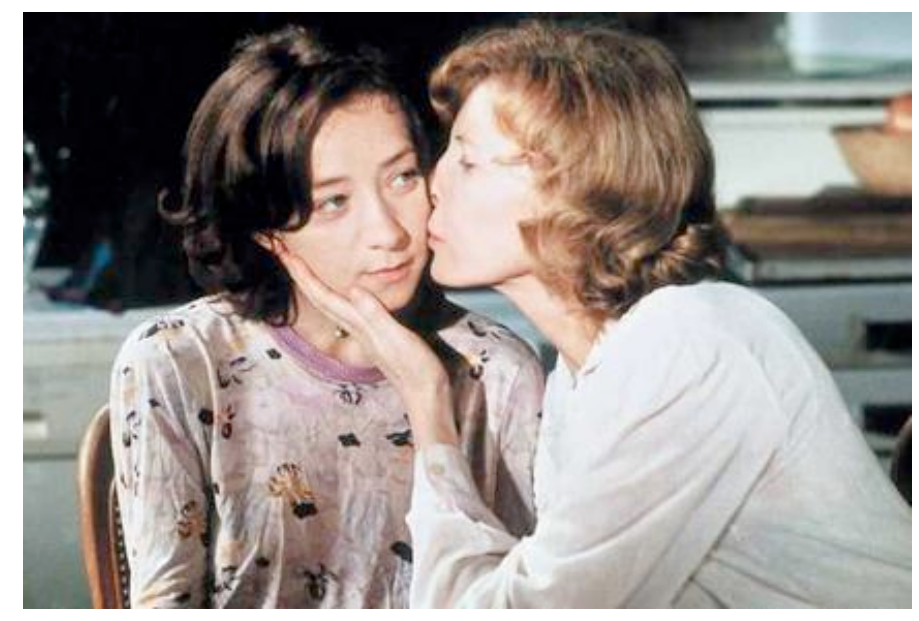

Full of words, framed by a fragile double spiral labyrinth through which the viewer accesses the installation, the filmic element of the installation is embedded in a sculptural structure that was also a temporal one. On repeated encounter with the installation, the logic and interrelations of the composition of three parts becomes a vital element of conveying both the fragmentation and dislocation through which the threads of

Griselda Pollock, The Long Journey: Maternal Trauma, Tears and Kisses in a Work by Chantal Akerman Studies in the Maternal 2(1) 2010, www.mamsie.bbk.ac.uk 
a traumatic past can be rewoven and resolved into new awareness, through words, spaces, filming, texts and images.

Filling the first space of the installation, there is double spiral structure of transparent tulle on which are streamed words moving too fast to read but leaving poetic and suggestive traces of the thoughts, readings and reflections of the artist and the grandmother. This structure purposively invokes memories of minimalist sculptor Richard Serra's bare, iron spiralling construction, Double Torqued Ellipse. Both Akerman and Serra exhibited at the Venice Biennale of 2000. Yet Serra's monumentality is entirely reversed by the way in which the sculptural forms of Akerman become animated screens for moving flows of words that almost too literally illustrate Virginia Woolf's modernist and feminist concept of a stream of consciousness. Writing of this relation to Serra in 2005, Nathan Lee comments: 'But where Serra stages a cathedral encounter, overwhelming and uplifting the spectator through his monumental cast-iron sublimities, Akerman fashions a weightless envelopment, a dissolving of self amid whirling transparencies.' 22

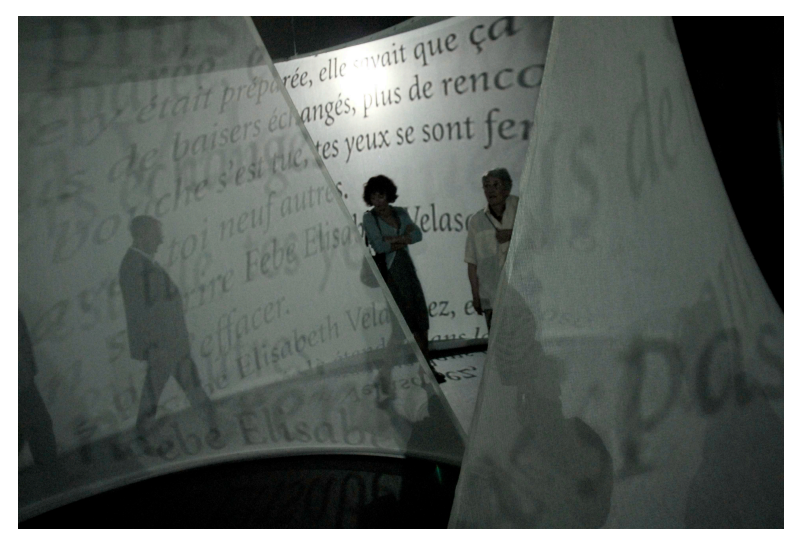

You can only access the installation by entering into the luminous, evanescent, curving, broken space that tensely balances both a modernist 'mother' and a minimalist 'father', movement and structure, text and surface. The viewer moves into a second room in the midst of which hangs a transparent tulle scrim in open space. On this scrim is projected a single painted portrait head of a young woman, dating from about the 1920s.

Griselda Pollock, The Long Journey: Maternal Trauma, Tears and Kisses in a Work by Chantal Akerman 
Then there is a moving image of a page of handwritten text that wanders across the scrim. The shared surface suggests a relation between the open pages of a notebook and this small portrait. Looking through the punctuated scrim, the viewer sees a large, doublescreen, out of focus, video projection. Over a period of 24 minutes, this projection unfolds the story of the filmmaker herself bringing to her mother a notebook/diary, asking her to read it, to translate its words from Polish, while her mother slowly comes to realise that she is reading the handwriting of her own mother, who wrote this diary as a teenager, and became a mother who was murdered in her thirties in 1942 in Auschwitz.

Having struggled with the poignant text that begins declaratively 'I am woman!' and tells the diary that she is, therefore, alone with the book as her only confidant, the mother of the filmmaker falls silent and reads the returning words of her own mother written long before she herself was born. At this stage the viewer cannot know what she is reading when she falls silent and ceases to translate or comment. The effect of what she reads is, however, sufficiently moving to make her turn, weeping slightly, and to caress her daughter's cheek, and then to kiss it.

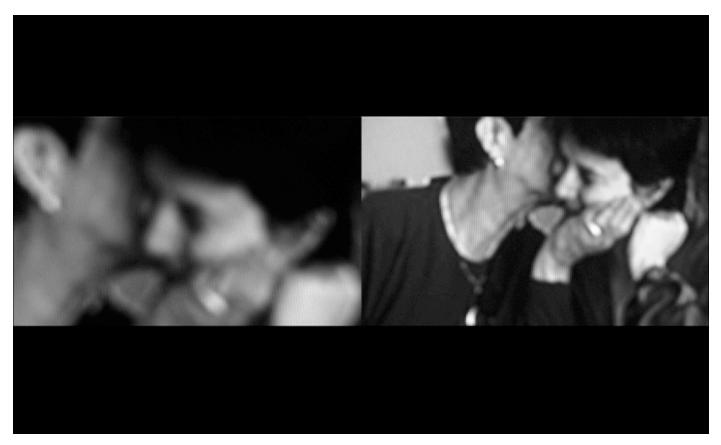

This gesture, enacted in silence in the middle of this manipulated double projection, functions as a hinge between the 'set-up' orchestrated by the filmmaker as 'research' for her movie to come and a time-reversing moment in which, for the student of Akerman's cinematic career, everything from the beginning becomes plain. Watching this work for the first time, I felt as if an entire career had been undertaken, movie after movie, and since 1995, art installation after installation, to arrive at that possibility, that moment, that gesture, captured not by the filmmaker looking through the lens, but as its

The Long Journey: Maternal Trauma, Tears and Kisses in a Work by Chantal Akerman

Studies in the Maternal 2(1) 2010, www.mamsie.bbk.ac.uk 
recipient, the skin brushed by the touch of the mother's hand and lips. That was what I can only name a pathosformel: a form-ulation for feeling in which the body and its gestures eloquently disclose what cannot easily be said. ${ }^{23}$

What caused the gesture? What caused me to read it in a specific way? It appears that in reading to the end of the written pages of the diary, Nelly Akerman discovered, as if for the first time, her own inscription in 1945 to her lost mother, when, as a bereaved eighteen-year-old, barely alive herself, she received this diary (she cannot remember how it came to her) as the only surviving relic of her murdered mother. She had written:

This is the diary of my poor mother who disappeared so early, at the age of 40. I will never forget her young girl's life, I will always think of her as the best mother who ever lived. I am sorry that I did not love her more and love her better than I loved her. She was so good and so understanding that she will remain in my heart always, singular and unique, and no one will ever replace her for me. My dear little mother, protect me. Nelly

But the diary had been found by the daughter of Nelly, Chantal when she was about ten (1960). She had found the inscription by her mother and added her own into this unique object, already overinscribed:

Dear Mama,

You can't imagine how I felt reading what you wrote in those few lines. I hope you feel protected and loved by all and that you are happy.

Chantal.

In turn, Chantal's younger sister also finds the diary and adds her own words:

Dear Mama,

I also felt something in my heart reading what you had written. No one can replace you dear Mama, I would have loved to know your beloved mother. Your daughter who loves so much.

Sylviane

I have highlighted the recurring word protection. It recalls the passage already quoted:

My mother gave it to me. She said, it will protect you. She gave it to me when I was in need of being protected and she felt powerless. She gave it to me instead of talking.

Protection signals its own opposite: anxiety and vulnerability. Those who have lived with or around survivors of the Holocaust or other utterly shattering traumas can fully appreciate what it means to have to live in the world after what is in effect a total

Griselda Pollock, The Long Journey: Maternal Trauma, Tears and Kisses in a Work by Chantal Akerman

Studies in the Maternal 2(1) 2010, www.mamsie.bbk.ac.uk 
destruction of the trustworthiness of others and the world not to encompass your destruction. Non-survivors cannot imagine, just as those who have never been bereaved cannot imagine the effect of the rupture that destroys an unquestioned confidence in persistence and security in relation to others. Thus this anxious need to provide protection is itself the deep symptom of the past passed onto the child who can never experience the unquestioned confidence, but must always sense an anxiety towards the world. But what is intensely striking in this accumulation of inscriptions is the deep compassion of the child towards the vulnerable parent, a compassion so beautifully explored in the work of Bracha Ettinger and located in the proto-ethical pre-birth encounter of mother-to-be and child-to-be in their co-affecting yet unknowable matrixial severality. ${ }^{24}$

The tears and the kiss are wordless; they are a response that returns to gesture as the movement towards, but also with, another, and returns to the touch, to a moment of affect and contact that does not dissolve difference but marks a shared moment and creates a surface of meeting. What follows from the gesture of touching her daughter's face and kissing it, affirming her being there, is a long free-flowing conversation between them about the past - firstly about the plans and pre-war ambitions of Nelly Akerman and her artistic mother to work in some aspect of design, couture perhaps, then the regrets of Nelly Akerman who returned from her experience in the camps 'damaged and broken', unable to take up her studies, and in need of the support offered by her husband, a leather merchant. Here is evidence of the mother as part of 'the sacrificed generation', men and women like Chantal Akerman's mother whose lives were so radically interrupted that mere survival after their experiences consumed their energies. Yet this conversation about what her mother had endured, how she had been supported by a friend through the devastating hunger of her time in the camps, and how she was liberated puts in place the long-missing 'story' without holes.

Born of a Polish-Jewish family settled in Belgium since the 1930s, Nelly Akerman had been arrested with her aunts and taken to Malines, known in Flemish as Mechelen, where in 1942 the SS had established in the Kazerne Dossin a Collection Camp, SSSammellager Mechelen, from which 24,916 Jewish people and 351 Roma and Sinti people were deported to death camps in the east. Only 1,221 people survived from these

Griselda Pollock, The Long Journey: Maternal Trauma, Tears and Kisses in a Work by Chantal Akerman 
transports from the transit camp. Protected by a woman named Frieda, moved from camp to camp across Germany in the final months of the war, Nelly was re-united with her aunts and aided initially by French deportees before being finally rescued and restored by American soldiers who gently fed the emaciated survivors with teaspoons of soup. The conversation also moves onto why Nelly Akerman supported her own daughter's artistic ambitions, even fighting her husband over his fears for his vulnerable girl-child in the shark-infested waters of the movie business. Thus we witness a historic moment when the traumatic past is opened up to words, to exchanges, questions and shared memories. We glimpse a new intimacy of stories shared and confirmed, and of spoken recollections.

IV

In notes, Akerman tells us that Aurore Clément, who would play the mother in Tomorrow we Move, watched this 'raw' footage. For the movie, the contents were fictionalised and words and names were changed. But then Aurore Clément took over something extraordinary from the filmed exchange. 'The Mother (Aurore) at one point says to her daughter Charlotte in the film (played by Sylvie Testud) "it's a miracle that I am here and that you're here, you know".' That is to say that the mother-to-be's survival at all was such an accident, that the very existence of a new generation is marked by the contingency of a survival that escaped the genocidal death sentence that engulfed millions. Akerman adds: 'My mother did not say that, when Renaud and I filmed her. At one point, Aurore kisses her daughter. In the film, we do not know why.' Then she continues:

In the images of my mother we do not know why either, why all of a sudden she kisses me. I know why, she has just discovered what I and my sister added. First, what she had written following her mother's last words. She did not remember it. She no longer remembered what she had written.

The film preparation in 2004 creates the moment in present time for an amnesic re-encounter with a forgotten repressed past. In another reversal, Akerman also tells us that her mother then watched Aurore Clément play the scene based on the filmed encounter.

Griselda Pollock, The Long Journey: Maternal Trauma, Tears and Kisses in a Work by Chantal Akerman

Studies in the Maternal 2(1) 2010, www.mamsie.bbk.ac.uk 
Suddenly I saw tears in her eyes. She tried to hold them back. But she could not. They were little tears, very discreet. The next day I telephoned and she was said, you know I was a little overwhelmed yesterday, but I finally feel better.

All these films have finally brought me to that. She finally feels better. She finally shed a tear. Thirty-three years of work with so many turns and detours, and she finally feels better. Is this what I was looking for?

I have no idea.

Maybe.

I'd like to believe it.

But honestly not just that.

The words can hardly contain what they mean; that finally, after all these years, Nelly Akerman feels better. In what way does the translation of the 'event-encounter' that happened with the diary before the digital camera in her own home into a formal scene played by others 'transform' her own lived burden of history, relieve her of feelings, make a change? I want to stress the transformation where the trans dimension of the movements between mothers and daughters, and then actors, links in with Ettinger's idea of metramorphosis. Metramorphosis as an aesthetic process provides creation of a form for passage, akin to that which Aby Warburg named a pathos-formulation, through which the trauma, that was always there as a constitutive void shared between mother and daughter, is now moved outside both of them by an aesthetic formulation that is the film. What is important is that the possibility for such an aesthetic formulation and hence passage from the void to the space of shared memory was itself precipitated and disclosed through the 'research' filming one Sunday in Brussels.

There is a danger here. The reader might think that we are finally finding the key, and a biographical key that unlocks the secrets of thirty-three years of Akerman's filmmaking. Reduction of a life-time's work to one single, autobiographical causation is utterly ridiculous. In one deep sense, as Akerman admits, it is just that, but then she adds importantly, [b] ut honestly not just that and it is to this 'not just' that we have to pay acute attention.

Yes, we do have to make sense of the belated moment of realisation when a single gesture and its replay and revisioning through the medium of digital recording and then cinematographic performance and registration appears to crystallise a shapeless haunting past into that which can be said, scripted, performed, watched, and taken on. There were two moments when the 'trauma' - which is what we are dealing with - I suggest, leaks

Griselda Pollock, The Long Journey: Maternal Trauma, Tears and Kisses in a Work by Chantal Akerman

Studies in the Maternal 2(1) 2010, www.mamsie.bbk.ac.uk 
out of the body in the flow of slight tearfulness. We are not confronting the wracking sobs of immediate, abreactive grief; rather Nelly Akerman's damp eyes that Sunday in Brussels and her 'discreet' tears on the film set are subtle moments when the body fluidly betrays itself. But such tears are a relief as gentle as that which is relieved is unspeakably enormous. The disproportion is the very sign of trauma.

I am not suggesting that suddenly in Brussels before Renaud Gonzalez's camera the truth of Akerman's cinema was revealed as the long-secreted family history of destruction and survival in the Shoah. Yet I am suggesting, as others before, that this is the historical ground that cannot be ignored in tracing the specific aesthetics and ethics of Akerman's long career to date precisely because its deepest core, by definition, could never be directly confronted. I want here to stress its emergence across the sequence of events: the filming, the watching of that footage, the watching of its being turned into cinema and, after all three events, there is the moment of flowing words (later formalised by streams of them flowing over the convoluted sculptural forms through which the installation is accessed). ${ }^{25}$ Conversation marks a different space, process and relation to past and future. There is the flow of words; unblocked, silenced burdens can find themselves uttered without destruction befalling the speakers. Yet before this moment, there was not this flow of tears - feeling better - nor words. Indeed silence or violent explosion, missed communication and absence, marked the cinematic rhetoric of Akerman in ways which found acceptance and acknowledgement as part of a feminist avant-garde, inspired by Godard, Snow and Warhol. We accepted the signs of her cinematic intervention, but we knew not the specifics of their causation in a deeper, still culturally unacknowledged trauma that flowed beside but was not reducible to the choked feminine voice in culture meeting a new cinematic formalism.

I want to draw attention to stories, or to the role of story-telling as a mediating process between a sensed dimension of unspoken pasts and a certain kind of structuration that parcels out this otherness in mediated doses. This opens onto two insights by scholars who work with the relations between traumatic history and cultural representation.

Writing of the failure to mourn in the German context, Eric Santner identified two contrary strategies in cultural practices in the aftermath of trauma. The first he named

Griselda Pollock, The Long Journey: Maternal Trauma, Tears and Kisses in a Work by Chantal Akerman 
'narrative fetishism,' invoking Freud's double structure of disavowal and memorialisation.

By narrative fetishism I mean the construction and deployment of a narrative consciously or unconsciously designed to expunge the traces of the trauma or loss that called that narrative into being in the first place... Narrative fetishism is the way an inability to mourn emplots traumatic events; it is a strategy of undoing, in fantasy, the need for mourning by simulating conditions of intactness, typically by situating the site and origin of loss elsewhere. ${ }^{26}$

The baulked disavowal of loss transferred to a monument for instance might have operated in the Akerman case through the repeatedly lost and refound diary. Santner contrasts this tendency to displace with the genuine process of the work of mourning, a process that must take place over time, through different sorties as it were:

The work of mourning is a process of elaborating and integrating the reality of loss or traumatic shock by remembering and repeating it in symbolically and dialogically mediated doses; it is a process of translating, troping and figuring loss, and, as Dominick LaCapra has noted [...], may encompass, a "relation between language and silence that is in some sense ritualized". ${ }^{27}$

Drawing on Freud's major redirection of psychoanalytical theory around 1915 from cathartic abreaction from trauma to an economic model of psychodynamic work (working through and the work of mourning) which involves both time and a processing in dialogical encounters and mediated doses, Santner suggests that, in fact, trauma may take a long time to be worked through, and that working through does not amount to a cure. It involves a process of reconfiguration of affects through symbolic articulations that translate, trope and figure loss. We do not ever get over loss, but loss can be worked into our systems for generating meaning and managing affects by formalisations which include symbolic language but also gestures and rituals. Trans-lation then becomes not only the alteration from one form to another, but carrying over between subjectivities: a transsubjective process.

In his essay 'On Traumatic Knowledge and Literary Studies', Geoffrey Hartmann, himself a Holocaust survivor and critical thinker of the Yale School of Deconstruction, writes: 'Traumatic knowledge would seem to be a contradiction in terms. It is as close to nescience [unknowing] as to knowledge. Any description or modelling of trauma, therefore, risks being figurative itself, to the point of mythic fantasmagoria., ${ }^{28}$ Trauma belongs to the 'real' (in the Lacanian sense) - but

Griselda Pollock, The Long Journey: Maternal Trauma, Tears and Kisses in a Work by Chantal Akerman

Studies in the Maternal 2(1) 2010, www.mamsie.bbk.ac.uk 
the real is not the real, in the sense of specific, identifiable thing or cause... the encounter with the real takes place, on the part of both analyst and analysand, with a world of deathfeelings, lost objects, and drives. It might be described, in fact, as a "missing encounter" (the troumatique, Lacan puns) or an unmediated shock. ${ }^{29}$

In Lacanian terminology the Real - the domain of trauma - lies behind and beyond fantasy (phantasm): the Imaginary, and it lies beyond thought: the Symbolic. The Real it- happens, but 'it' occurs before the still-to-become subject has developed a psychic apparatus by means of which to metabolise the incoming event, to translate it, to process it, to imagine with it or to think about it. Trauma is thus a structural term for a condition of human receptivity to, and for the non-verbal intensitities and affectivities resulting from the impact of, incoming stimuli from the world outside and even from the protosubject's own organic events (babies are frightened by their own cries, distressed by inner operations of their digestive systems and so forth). 'It' happens but there is not yet an 'I' to know what 'it' is or even that 'it' has happened and whose event 'it' is. For Lacan, this is the realm of the Thing before the elements of the world can become objects within the psychic system of drives and interpersonal relations by means of which the subject achieves satisfaction or creates meanings.

In the later stages of his thinking, however, Lacan recognised the need and the possibility for psychoanalytical reflection on the psychic domain that lies between trauma (the Real) and fantasy (the Imaginary), an expanse which Bracha Ettinger is suggesting has become a key field of research in contemporary artistic practice, and for deeply historical reasons. ${ }^{30}$ We live, historically, in a post-traumatic era, that is to say, coming after events of such an extremity and accumulation that they challenge modes of understanding and representation based on what preceded them. 'We', the late-coming witnesses to events that are not our own, through time or geopolitical difference, nonetheless are affected unconsciously by the traces of these disturbances as they resonate across culture: in how we think about human sociality and ethico-political living together after such atrocities against humanity. But working in the space between trauma and phantasy is also a possibility because of the potentialities created by expanded, contemporary artistic practices that have the freedom to work with so many processes without being confined by critical orthodoxies and formalist constraints while yet being

Griselda Pollock, The Long Journey: Maternal Trauma, Tears and Kisses in a Work by Chantal Akerman 
able to harvest from the formal turn different resources for this project. Thus translation of trauma involves the specifics of aesthetic formulations.

Elaborating the psychoanalytical concept of trauma in the field of cultural analysis for literature (and art), Geoffrey Hartman, therefore, suggests that that which he names literary knowledge, 'finds the "real", identifies with it.' He continues:

This leads towards literary theory, because the distinction between experiencing (phenomenal or empirical) and understanding (thoughtful naming, in which words replace things, or their images) is what figurative language expresses and explores. The literary construction of memory is obviously not a literal retrieval but a statement of a different sort. It relates to the negative moment in experience, to what in experience has not been, or cannot be, adequately experienced. That moment is now expressed, or made known in its negativity; the artistic representation modifies the part of our desire for knowledge (epistemophilia - desire for knowledge) which is driven by images (scopophilia - desire to see). Trauma theory throws light on figurative or poetic language, and perhaps symbolic process in general, as something other than an enhanced imaging or vicarious repetition of a prior (non)experience. ${ }^{31}$

Hartman here emphasises the possibility of creating, through art or literature, a kind of figuration, or a rhetorical means by which the unknown and unexperienced may, none the less, be introduced in an indirect, not-represented form into the realm of cultural knowledge, 'in the negative'. The traumatic event or its affects are not represented; yet through art or literature that can perform more than representation, something of trauma's radical otherness may be encountered. Something is the key word here. Not everything, but some aspects may be encountered through the formal work that shapes a space for the encounter. More importantly, the original, creative gesture of art, itself a response to what it will only be able to recognise afterwards as engendering it, becomes an originary site for an encounter with the affective ripples around the non-experienced, hence, absent traumatic pool, so that we come to know about trauma rather than reducing it to a representation it cannot but evade. Hartman continues:

Periphrasis, for example, as it moves toward the riddle... indicates a real whose indeterminacy creates a tension between signified (solution to the riddle) and signifier (the riddle form). Since every object can be riddled this way... this tension is constitutive rather than provisional and opens a creative play-space, the possibility of singing "in the face of the object" (Wallace Stevens). ${ }^{32}$

Riddling and playing - both suggesting repetition and time - emerge as a perplexing mode of accessing a negative knowledge of the unknowable, which does not raise the traumatic to some sublime inexpressibility before which we declare we cannot know

Griselda Pollock, The Long Journey: Maternal Trauma, Tears and Kisses in a Work by Chantal Akerman

Studies in the Maternal 2(1) 2010, www.mamsie.bbk.ac.uk 
anything. When aesthetic or literary activity creates its forms, these are not a repetition of that which already exists as a memory or a known event in the subject or in culture. There cannot be repetition because that to which art or literature is giving a form, and is doing so for the first time, creating a form by means of which to know it affectively, is, in fact, a negative moment in experience. Art/Literature creates what has neither yet, nor ever, entered into experience, that being the definition of trauma. Art can be, however, periphrasitic rather than constative, moving around the elusive 'something' that structures subjectivity and pressing towards its own inscription, and yet is impossible to know while being both affecting and significant. Trauma is the exceptional non-experience that, nonetheless, aesthetic practices access through creating new modes for the other's encounter with its traces, remnants, or scenes.

Artworking about trauma risks being traumatic; but it can also stage both a passage back to encounter the residues of trauma and a passage away from it -precisely when the artwork disrupts, through the forms it offers to the viewer to experience and the gazing it invites, the hunger for mastery (epistemophilia) and the sadism of voyeurism (scopophilia).

If we focus on the negative moment in experience, the traumatic, the real, which apparently is encountered again, but effectively for the first time in the art work as its formulation, (in pathosformel, in Warburg's terms), we need to ask what is the relation of aesthetic practice to the structural trauma of the archaic encounter which may condition its very possibility, and to historically traumatic events that may determine the subject's later actions which become sites of the created memory of the unremembered, what Bracha Ettinger has termed 'the memory of oblivion'? ${ }^{33}$ By this she is stressing the creation of a memory of that which, having never been known, cannot be said to have been forgotten and then remembered. Such a new form of memory, involving duration and reflection, opens onto a future by creating a passage with the trauma that has remained latently at work for the lack of such delivery into forms by which we can transform its legacies. For this work, Bracha Ettinger has proposed a new term; fascinance, while she also revises the concept of encryption with the term transcryptum.

Griselda Pollock, The Long Journey: Maternal Trauma, Tears and Kisses in a Work by Chantal Akerman

Studies in the Maternal 2(1) 2010, www.mamsie.bbk.ac.uk 
Fascinance is an aesthetic event that operates in the prolongation and delaying of the time of the encounter-event and allows a working-through of matrixial differentiating-injointness and co-poesis. Fascinance can take place only in a borderlinking within a real, traumatic or phantasmatic, compassionate hospitality. ${ }^{34}$

Ettinger's concept is elaborated through her re-reading of the core psychoanalytical case study of the daughter; 'Dora'. Of 'Dora's' dream/memory of gazing for two hours at Raphael's Dresden Madonna, Ettinger writes:

Dora constituted contemplative relations of fascination with the Madonna since this image served for her the function of fascinance. Dora created the moment of looking at the Madonna's painting as a matrixial encounter-event by her unconscious urge to produce transformation in the traces of imprints of earlier moments of encounter that had failed. The daughter solicits fascinance within the girl-mother relations. ${ }^{35}$

For Ettinger, the daughter-girl-Dora solicits an encounter that is not castrative; it is non-Oedipal and does not produce in her a sense of lack. It does, however, relate to finding out about sexual difference, but sexual difference as feminine specificity rather than as negative lack vis-à-vis the masculine. This encounter involves a prolonged contemplation of the meaning of a sexual difference 'from the feminine' that is not the effect of castrative, hence phallic Oedipalisation. Such difference, which is sexuating but not gendering, results from the always-already archaic sexual difference of the matrixial feminine (expressed by Ettinger as archaic severality of partial subjectivities encountering each other and co-affecting in minimal difference). Post-natally, the girl-child needs to 'work through' this potentiality, however, as part of her own exploration of femininity. Ettinger suggests that the question of what a woman wants/desires is to be discovered by the gaze of fascinance addressed to an-other-m/other-woman, namely, ffAm or femmefatale-Autre-mère or ffam (pronounced as the word woman in French: femme). Ettinger affirms: 'In the matrixial encounter, the private subjectivity of the individual is momentarily unbounded. The psyche momentarily melts, and its psychic threads are interwoven with threads emanating from objects, images, and other subjects. In a matrixial encounter with an image, a transformation occurs. ${ }^{36}$ Thus instead of the biographical model in which we might confine Chantal Akerman, her mother and her grandmother, the cinema of Akerman can be read as a prolonged staging and contemplation of the moments of a necessary fascinance addressed in the structural sense of the Other/mother who offers grounds for feminine subjectivity and sexualities and in a

Griselda Pollock, The Long Journey: Maternal Trauma, Tears and Kisses in a Work by Chantal Akerman 
historical sense to the lost artist-grandmother and the survivor-daughter-become-mother. 37 Fascinance might help understand Akerman's cinema of attention and duration, ambivalent in its tones of love and violence, its play of pathos and crazy humour.

The second Ettingerian concept I want to introduce is transcryptum. It extends matrixial potentiality for trans-subjectivity into aesthetics and trauma studies. Ettinger builds on the work of psychoanalysts Nicholas Abraham and Maria Torok who posited a psychic crypt in which is buried an unprocessed traumatic loss without memory. Not connected with actual loss, and not touched by either mourning or its stalling in melancholy, the crypt contains a haunting phantom occasioned, according to André Green, by the change (or shall we say failure?) of the maternal imago because of the mother's own grieving, depression or unresolved losses that are not spoken but are, nonetheless, sensed by her uncomprehending yet matrixially sensitised child. The child of such a parent is linked to the loss in the parent, identifying with what Green names the psychologically 'dead mother. ${ }^{38}$

Thus we have on the one hand the idea of an individual living with an encrypted trauma or loss, and on the other, the impact of that unmourned encryption on the child of such a subject, implying an intergenerational transmission of trauma. Ettinger expands both Green's and Abraham and Torok's thoughts to theorise how a child 'invests libidinally in the traces of someone else's trauma in the psychic apparatus.' Matrixially, the encrypted loss produces a transcryptum in which a subject not only assumes memories of pasts she did not live, but is shaped by non-memories, the traumatic holes of the Other, and at the same time takes them on, working with them, sometimes creatively. Ettinger draws upon other Freudian concepts, namely the uncanny, in order to explore the ways in which aesthetic processes undo boundaries and transgress borderlines between discrete subjects, across which affects are transferred, instantiating transsubjective transmissions.

I submit that a crypt-with its unburied unthought of knowledge, with what cannot be admitted and signified by the m/Other as loss and is buried alive in an isolated nonconscious cavity, with the traumatism that caused it, with the signifiers that could have told the story, but instead remain detached and isolated, with the image that could have held together the scene, and with the affect that had accompanied it- can be transmitted from one subject to another by metramorphosis, because a capacity and an occasion for this kind of transmission, co-affectivity, co-acting, ad co-making already occurred in the archaic relation between each becoming-subject and the m/Other. Metramorphosis turns the

Griselda Pollock, The Long Journey: Maternal Trauma, Tears and Kisses in a Work by Chantal Akerman

Studies in the Maternal 2(1) 2010, www.mamsie.bbk.ac.uk 
subject's boundaries into thresholds, and co-affectivity turns the borderlines between subjects in distance-in-proximity and between subject and object, into a shareable borderspace. $^{39}$

Ettinger's insights point in two directions at once. Looking one way we can sense the structural condition of susceptibility to transmitted trauma: to the passing on of holes and voids that shaped several subjects' shared psychic terrain. But from another perspective (the matrixial as aesthetic agency working through metramorphosis), this shareability opens up the possibilities of passages through which the blocked, repressed and repeating voids are transformed at a borderspace where translation may occur.

When I first experienced Akerman's installation Walking... in Berlin in October 2007, I suddenly felt as if an entire cinematic journey had been undertaken by Akerman and her viewers to arrive at this moment that 'it' could happen, before the camera but 'with her being with her mother' in front of its discovering attention. It was as if having seen and felt this work, it would now be necessary to review every previous Akerman film and see in it another dimension. It would not be a matter of all previous films encoding this discovered truth. Rather a whole practice over time now could be seen as forming mediated, riddling, periphrastic doses of gentle and subtle movements backwards and towards this kernel of transmitted and shared losses that were also the source of new creative energies, sometimes violently explosive as in Saute ma Ville, sometimes stilled and deadly as in Jeanne Dielmann, but always animated by a compassion for the suffering that was at once other and within. It is as if the whole body of work by Akerman, touching on many other subjects in a long and now truly appreciated career as one of Europe's leading filmmakers working with sexuality, cultural difference, dislocation and storytelling, and cinema itself has finally found a means to confront the unspoken history, not just of massive absence and terrible dying that was intimated in the railway scene in Germany in Rendez-vous D'Anna (1978) and more formally in the twenty-fifth screen of D'est (From the East) (1995), but of the one death that is her mother's loss, and is her own personal heritage of historical rupture as personalised loss in the maternal line.

Griselda Pollock, The Long Journey: Maternal Trauma, Tears and Kisses in a Work by Chantal Akerman

Studies in the Maternal 2(1) 2010, www.mamsie.bbk.ac.uk 
The spontaneous gesture, the mother's teary kiss captured that afternoon in the Brussels apartment by a casual filming, does not heal the breach. It cannot repair the rupture. It cannot erase the past. It is the moment that the past became the past, allowing a movement into narrative and into the flow of dialogical speech. The mother later says in this video, 'I am glad that I lived to see this day.' The enormity of two lifetimes is hardly contained in the simplicity of this statement. The filming allows into that impossible space of mourning and com-passion, the child's feeling for the parent as a bereaved daughter, a solace that is as painful as it is a relief of a hitherto unspoken but now shared burden. $^{40}$ The physicality of her spilling tears and her touch of the skin of her own daughter, for which the 'research' filming for the other movie set up the occasion, allows the body to speak so as to make possible the narrative that releases the silent, encrypted trauma into aesthetically occasioned, and shareable memory. After it, captured on the digital camera, mother and daughter begin to talk about the past, about the mother's story, her experiences in the camp, making a new life afterwards, and how she allowed Chantal Akerman to become an artist and not a dealer in leather-goods, to become the artist neither her own mother nor she had been able to become. They talk about her father's resistance to what he saw as a vulnerable career in filmmaking as a young woman. They mention the first screening of Saute Ma Ville on TV when her father was alive. In that film, made when Akerman was only eighteen, a young woman (played by Akerman herself) mimics the housewife; she cooks, cleans, sings, dances and finally gasses herself, blowing up her whole town.

Such invisible and illogical violence was not critically received at the time as an inscription of trauma, and certainly not related back to the burden of Jewish family history. I would contend, however, that Saute Ma Ville did register a traumatic inflection, in this gesture of absolute destruction that was not directed against either her family or her hometown. Instead, its excess functions as a form of succumbing, by joining to an unspeakable, senseless sense of inherited destruction which, as is trauma's habit, can only be mimetically acted out as the road to personal freedom to become the artist she (Chantal Akerman and her grandmother/mother) wished to be.

Griselda Pollock, The Long Journey: Maternal Trauma, Tears and Kisses in a Work by Chantal Akerman 
How long did it take for us, for me, for her as the author of this work, not only to realize the traumatic core exploding into a future cinematic career but to be able to articulate it, non-reductively and with compassion? It is thus a cultural history of what can and cannot be said, in specific relation to the shadow of the Shoah in culture that can be tracked carefully through the work of Akerman. Talking with her mother in Walking/Marcher of the TV screening of Saute Ma Ville, Akerman avows that she never again managed this perfect combination of the tragic and the comic that she relentlessly sought, a combination she suggests is born of the predicament of Holocaust survivorship that can only manage the violent pain through the deflection of comedy.

My conclusion is not that we can now retrospectively place Chantal Akerman in a category, genre, or group sometime identified with the Shoah, for that would be to contain or fail entirely to recognize the work performed by her artworking. What I am left with is a question about a journey.

In effect I have been asking if we travel away from or towards trauma? If I can track a certain persistence that only retrospectively appears to us as having been the thread of continuity underlying a forty-year career, is it possible that the past only arrives once a future has been built to contain it? Whose life does this body of film create?

In one reading, the work of Akerman belatedly reveals its deeply traumatic structuration to which her own comments bear regular witness. In a matrixial reading, however, a certain fidelity reveals more than obsession or repetition compulsion. Fidelity witnesses fascinance: a prolonged and necessary contemplation of a certain enigma lying between mother and daughter precisely in those zones that are also mother as daughter with her missing mother. Walking/Marcher is not the final key. It is the scene that independent cinema, bleeding into contemporary installation time-based art, made possible. The matrixial trauma of the lost mother/grandmother-matrixial severality could be reapproached and transported through occasioning and being able to witness the matrixial compassionate gesture of the daughter to her orphaned mother so that she could become the mother the daughter herself needed. Something happened that Sunday in Brussels that had waited long to occur in the intertwining lives of both women. In Nelly Akerman's silent return to the site of her own inscription to her mother and the discovery of both her

Griselda Pollock, The Long Journey: Maternal Trauma, Tears and Kisses in a Work by Chantal Akerman 
daughters' compassionate embrace of her and her loss, she makes a gesture accompanied by the soft seep of tears to reach out, touch, stroke and kiss her daughter. I remain myself caught in my own fascinance before this image that strokes and touches something in me of which I cannot speak, but which I can know through writing of this other journey home.

${ }^{1}$ I am deeply grateful to Chantal Akerman and to Marion Goodman for providing me with English translations of the artist's statements. This paper is part of a forthcoming book: After-affect/After-image: Trauma and Aesthetic Encryption in the Virtual Feminist Museum.

${ }^{2}$ The original French title includes the phrase: 'Marcher à côté de ses lacets' which is an idiom meaning 'to be completely out of it.'

${ }^{3}$ Bordering on Fiction: D'Est was premiered at the San Francisco Museum of Modern Art in January 1995; it was then shown at the Walker Art Gallery, Minneapolis and toured to the Galerie Nationale du Jew de Paume, in Paris, Société des Expositions des Beaux Arts in Brussels, Kunstmuseum Wolfsburg, Germany, and the UVAM Centre des Carme in Valencia, Spain. I saw it at the Jewish Historical Museum in New York. It was conceived by Chantal Akerman, Kathy Halbreich, Catherine David, Bruce Jenkins, Michael Tarantino and Susan Dowling. It was based on journeys to Eastern Europe undertaken by Chantal Akerman in 1992 and 1993. See Bordering on Fiction: Chantal Akerman's D'Est, edited by Kathy Halbreich and Bruce Jenkins (Minneapolis: Walker Art Center, 1995) and Kristine Butler, 'Bordering on Fiction: Chantal Akerman's From the East' in Identity and Memory: The Films of Chantal Akerman, edited by Gwendolyn Audrey Foster (Trowbridge: Flicks Books, 1999), pp 162-178; Alisa Lebow, 'Memory Once Removed: Indirect Memory and Transitive Autobiography in Chantal Akerman's D'Est', Camera Obscura, 52, 18:1 (2003), pp. 35-83.

4 Jean-Luc Outers, Histoires d'Amérique' Cinérgie (February, 1989), 6; translated in Janet Bergstron; 'Invented Memories' in Identity and Memory: The Films of Chantal Akerman, edited by Gwendolyn Audrey Foster (Trowbridge: Flicks Books, 1999), pp. 98.

5 Janet Bergstron, 'Invented Memories'; Alisa Lebow, 'Memory Once Removed: Indirect Memory and Transitive Autobiography in Chantal Akerman's D'Est', Camera Obscura, 52, 18:1 (2003), pp 35-83. I am using the hyphenated trans-formed as later I will stress the word form-ulated in order to insist repeatedly on the discovery or a form for hitherto formless trauma. It will relate to the underlying influence of Aby Warburg's conceptualisation of the image as a formula for pathos: emotion.

${ }^{6}$ Claude Lanzman, Shoah: The Complete Text (New York; Da Capo Press, 1995), pp. 3

${ }^{7}$ Helen Epstein, Children of the Holocaust: Conversations with Sons and Daughters of Holocaust Survivors (New York: Putnam Books, 1979); Anne Karpf, The War After: Living with the Holocaust (London:

Griselda Pollock, The Long Journey: Maternal Trauma, Tears and Kisses in a Work by Chantal Akerman Studies in the Maternal 2(1) 2010, www.mamsie.bbk.ac.uk 
Faber,1996); David Grossman, See Under Love (New York: Farrar, Straus, and Giroux, 1989); Gila Almagor The Summer of Aviya (1985, released as a film, 1988); Art Spiegelman, Maus: A Survivor's Tale (1986 and 1991). Anne Karpf, The War After: Living with the Holocaust (London: Mandarin, 1997).(Is it right that the Anne Karpf is in here twice?)

${ }^{8}$ Louise J. Kaplan, Lost Children: Separation and Loss between Parents and Children (London: Harper Collins, 1995), pp. 223-4. Transposition is the term coined by Judith Kestenberg in her work in 1972 with children of Holocaust survivors.

${ }^{9}$ Manuscript materials provided by Marion Goodman Gallery, Paris. They are the English translation of the materials printed in Chantal Akerman, Neben seine Schnürsenkeln in Einem Leeren Kühlschrank Laufen (Berlin: Jüdisches Museum und Laconic Press, 2007).

10 I owe this insight to Bracha Ettinger and I have written about its implications in my Resonance/Overlay/Interweave: Bracha Ettinger in the Freudian Space of Memory and Migration (Leeds: CentreCATH Documents, 2010).

${ }^{11}$ Jean-Jacques Moscovitz articulates this question in Lacanian terms in his book, D'ou Viennent les Parents (Paris: Armand Colin Editeur, 1991).

${ }^{12}$ Marianne Hirsch, Family Frames: Photography, Narrative and Postmemory (Cambridge MA: Harvard University Press, 2002).

${ }^{13}$ On Spiegelman's use of photographs in his otherwise illustrated work, see Marianne Hirsch, 'Surviving Images: Holocaust Photographs and the Work of Postmemory', Yale Journal of Criticism, 14.1 (2001), 537.

${ }^{14}$ On women and the diary as desired interlocutor see Rozsika Parker and Griselda Pollock, ed. The Journal of Marie Bashkirtseff (London: Virago Books, 1985) and the case of the diary of Anna Frank which was addressed to an imaginary friend, 'Kitty'.

${ }^{15}$ Luce Irigaray, 'Women's Exile', Trans. Couze Venn. Ideology and Consciousness, 1 (1977), 62-76; Luce Irigaray, 'The Bodily Encounter with the Mother' in The Irigaray Reader edited by Margaret Whitford (Oxford: Basil Blackwell, 1991), pp. 34-46. For a beautiful cinematic exploration of the concept of woman a derelict and exile in phallocentric culture see Sally Potter The Golddiggers (BFI, 1983; DVD, 2009).

${ }^{16}$ Virginia Woolf, 'Professions for Women' [1931] in Virginia Woolf, Women and Writing introduced by Michèle Barrett (London: The Women's Press, 1979), pp. 60.

${ }^{17}$ Virginia Woolf, 'Professions for Women' [1931] p. 62

${ }^{18}$ Griselda Pollock, 'Stilled Life: Traumatic Knowing, Political Violence and the Dying of Anna Frank' Mortality, 12:2 (2007), 124-141.

${ }^{19}$ Bracha Ettinger, Matrix Halal(a) Lapsus: Notes on Painting (Oxford: Museum of Modern Art, 1992), p. 85.

${ }^{20}$ Brenda Longfellow, 'Love Letters to the Mother: The Work of Chantal Akerman', Canadian Journal of

Griselda Pollock, The Long Journey: Maternal Trauma, Tears and Kisses in a Work by Chantal Akerman Studies in the Maternal 2(1) 2010, www.mamsie.bbk.ac.uk 
Political and Social Theory Annual, 13:1-2 (1989), 84.

${ }^{21}$ This concept is elaborated by Bracha Ettinger in her paper 'Transcryptum', in Linda Belau and Petar Ramadanovic, eds.,Topologies of Trauma: Essays on the Limit of Knowledge and Memory (Other Press: 2002), pp. 251-72.

${ }^{22}$ Nathan Lee 'Pleasures of the Text', Film Comment (September-October, 2005), 17.

${ }^{23}$ The concept of pathosformel comes from the work of Hamburg art historian Aby Warburg (1866-1929), who focussed on the ways in which certain visual formulae encoded profound emotions, remembering the once enacted rituals and gestures and providing a means of both transmission of the emotional charge and the representation of its memory. There is no formal definition of this concept that pervades the work of Aby Warburg. The sources for our understanding of this concept are Ernst Gombrich, Aby Warburg: An Intellectual Biography (Oxford: Phaidon Press, 1970) and Georges Didi-Huberman, L'Image-survivante: Histoire de l'Art et Temps des Fantômes Selon Aby Warburg (Paris: Editions de Minuit, 2002).

${ }^{24}$ Bracha Ettinger, 'From Proto-ethical compassion to Responsibility: Besideness and three Primal Motherfantasies of Not-enoughnesss, Devouring and Abandonment', Athena: Filosofijos Studijos, no.2 (2006), $100-136$.

${ }^{25} \mathrm{I}$ am reminded here of the use of Irigarayan imagery of the frozen wasteland turning to flowing water as the structure for Sally Potter's The Golddiggers (BFI, 1983) which represents through landscape a journey undertaken by two women to deconstruct the patriarchal formation of femininity and come to their own, collaborative recognition of femininity under the sign of movement and fluidity.

${ }^{26}$ Eric Santner, 'History beyond the Pleasure Principle: Some Thoughts on the Representation of Trauma' in Saul Friedlaender, ed., Probing the Limits of Representation: Nazism and the "Final Solution" (Cambridge, MA: Harvard University Press, 1992), p. 144.

${ }^{27}$ Eric Santner, 'History beyond the Pleasure Principle: Some Thoughts on the Representation of Trauma', pp. 144.

${ }^{28}$ Geoffrey Hartmann, 'On Traumatic Knowledge and Literary Studies', New Literary History 26:3 (1995), 537.

${ }^{29}$ Geoffrey Hartmann, 'On Traumatic Knowledge and Literary Studies', pp. 539. (I'm not sure why this space is here?)

${ }^{30}$ In The Matrixial Gaze (1995) reprinted in Bracha Ettinger, Matrixial Borderspace, edited by Brian Massumi (Minneapolis: University of Minnesota Press, 2006), pp. 73-80, Bracha Ettinger identifies research in this archaic domain in the varied works of Pierre Fédida, Jean François Lyotard (Figure/Discours) Christopher Bollas (The Shadow of the Object) and others in object relations such as Donald Meltzer.

${ }^{31}$ Geoffrey Hartmann, 'On Traumatic Knowledge and Literary Studies', 540.

Griselda Pollock, The Long Journey: Maternal Trauma, Tears and Kisses in a Work by Chantal Akerman Studies in the Maternal 2(1) 2010, www.mamsie.bbk.ac.uk 
32 Geoffrey Hartmann, 'On Traumatic Knowledge and Literary Studies', 540. Hartmann references Winnicott's Playing and Reality (1971) in relation to play-space.

${ }^{33}$ Bracha Ettinger, Matrix Halal(a)-Lapsus: Notes On Painting (Oxford: Museum of Modern Art, 1993), p.

${ }^{34}$ Bracha L. Ettinger, 'Fascinance and the Girl-to-m/Other Matrixial Feminine Difference' in Griselda Pollock, ed., Psychoanalysis and the Image (Boston and Oxford: Blackwell's 2006),

${ }^{35}$ Bracha L. Ettinger, 'Fascinance and the Girl-to-m/Other Matrixial Feminine Difference', pp. 61.

${ }^{36}$ Bracha L. Ettinger, 'Fascinance and the Girl-to-m/Other Matrixial Feminine Difference' pp. 62.

${ }^{37}$ On the significant distinction between structural trauma, theorised by psychoanalysis, and historical, traumatic events which inherit the unbound affects of structural trauma, see Griselda Pollock, 'Art/Trauma/Representation', parallax, 50 (January-March 2009), 40-54.

${ }^{38}$ André Green, 'The Dead Mother' in On Private Madness edited by Gregoria Kohon (London: Hogarth Press, 1986), p. 142-173; Nicholas Abraham and Maria Torok, The Shell and the Kernell, edited and translated by Nicholas T. Rand (Chicago: University of Chicago Press, 1994).

${ }^{39}$ Bracha L Ettinger, 'Transcryptum: Memory, Tracing in/for/with the Other' in The Matrixial Borderspace, 166.

${ }^{40}$ The term com-passion is a neologism created by Bracha Ettinger to stress the 'withness' of feeling with rather than for another. Bracha Ettinger, 'From Proto-ethical Com-passion to Responsibility: Besideness and three Primal Mother-fantasies of Not-enoughnesss, Devouring and Abandonment', Athena: Filosofijos Studijos, no.2 (2006), 100-136. See also Studies in the Maternal issue 3.

Griselda Pollock, The Long Journey: Maternal Trauma, Tears and Kisses in a Work by Chantal Akerman Studies in the Maternal 2(1) 2010, www.mamsie.bbk.ac.uk 